Instructions for authors, subscriptions and further details:

\title{
Sexual Commercialization and Masculine Rhetoric: The Problem of Prostitution in Spain
}

\author{
Águeda Gómez ${ }^{1}$ \\ Silvia Pérez ${ }^{1}$ \\ Rosa Verdugo ${ }^{2}$
}

1) Universidad de Vigo, Spain

2) Universidad de Santiago de Compostela, Spain

Date of publication: October $21^{\text {st }}, 2015$

Edition period: October 2015-February 2016

To cite this article: Gómez, A.; Pérez, S. and Verdugo, R. (2015). Sexual Commercialization and Masculine Rhetoric: The Problem of Prostitution in Spain. Masculinities and Social Change, 4(3), 241-269.doi:

10.17583/MCS.2015.1511

To link this article: http://doi.org/10.17583/MCS.2015.1511

PLEASE SCROLL DOWN FOR ARTICLE

The terms and conditions of use are related to the Open Journal System and to Creative Commons Attribution License (CC-BY). 
pp. 241-269

\section{Sexual Commercialization and Masculine Rhetoric:}

\section{The Problem of Prostitution in Spain}

Silvia Pérez, y Agueda Gómez

Universidad de Vigo, Spain

Rosa Verdugo

Universidad Santiago de Compostela, Spain

\section{Abstract}

This article is focused on the study conducted on prostitution customers in Spain with the purpose of understanding why men pay for sex. In order to answer this question, the discourses of prostitution customers were analyzed through semistructured in-depth interviews, group interviews and discussion groups. With the aim of coherently structuring the obtained narrations and classifying them in categories, the theoretical framework "frame analysis" was implemented. Four typologies of ideal customers were obtained: the misogynistic (hatred for women); consumerist (everything can be bought and sold); friend (affective though abusive); and critical (occasional and repentant). As far as we are concerned, the purchase of sex is not produced by the search for quality sex, fun and hedonistic enjoyment, but rather for a strategy to reinforce masculinity based on an identity focused on exhibition in front of a group of peers.

Keywords: Gender, prostitution, users of prostitution, frame analysis, theories of masculinity 
pp. 241-269

\section{Comercialización Sexual y Retórica Masculina: El Problema de la Prostitución en España}

Silvia Pérez, y Agueda Gómez

Universidad de Vigo, Spain

Rosa Verdugo

Universidad Santiago de Compostela, Spain

\section{Resumen}

Este artículo se centra en el estudio llevado a cabo entre los clientes de prostitución en España con el fin de comprender por qué los hombres pagan por sexo. Para responder a esta pregunta, se analizaron los discursos de los clientes de prostitución a través de entrevistas en profundidad semidirigidas, entrevistas grupales y grupos de discusión. Con el objetivo de estructurar coherentemente los relatos obtenidos y clasificarlos en categorías, se puso en práctica el marco teórico "frame analysis". Se obtuvieron cuatro tipologías de clientes ideales: misógino (odio a las mujeres); consumista (todo puede ser comprado y vendido); amigo (afectivo aunque abusa); y crítico (ocasional y arrepentido). Desde nuestra perspectiva, la compra de sexo de pago no se produce por la búsqueda de sexo de calidad, diversión y disfrute hedonista, sino que es una estrategia de refuerzo de una masculinidad conformada por una identidad que gira en torno a la exhibición frente al grupo de pares.

Palabras clave: Género, prostitución, clientes de prostitución, frame analysis, teorías de la masculinidad 
T he present paper wishes to contribute to the debate around the phenomenon of prostitution in Spain, analyzing an aspect of this reality that has not been studied in depth: the prostitution seekers or customers ${ }^{1}$. Due to the complexity of the concept of prostitution and the methodological difficulties for its quantification, it is difficult to provide exact figures to help us understand the real magnitude of the phenomenon. According to a UN report from the year 2000, around 4 million people in the world practice prostitution every year, generating a value for the so-called "sex industry" worth around 7 trillion US Dollars per year $^{2}$. In the case of Spain, a report from the year 2007 carried out by the "Comisión Mixta de los Derechos de la Mujer y de la Igualdad de Oportunidades del Congreso de los Diputados de España" (Mixed Committee for Women's Rights and Equality of Opportunities from Spanish Parliament) indicated that around 300,000 female prostitutes exist, while the vast majority of customers, $99.7 \%$, are men. Furthermore, the abovementioned report estimates that the business of prostitution in Spain creates 18 billion euros per year and that the Spanish expenditure in prostitution is around 50 million per day ${ }^{3}$. Certainly, this vast expenditure in prostitution services is linked to a high number of consumers, as understood by a poll conducted by the Centro de Investigaciones Sociológicas (CIS) [Center for Sociological Research] in 2009, that estimates that $32.1 \%$ of men have paid at least once to have sexual intercourse.

The contrasted rise of sex purchasing is producing adverse effects with a clear impact in prostitution: The increase of sex trafficking. The fight against sex trafficking became part of the political agenda of the United Nations on the year 2000 where, through the Palermo Protocol, the definition was stablished and incorporated to the legislation of the state members (Spain incorporated it late and incomplete). The work of the social movements, over all feminists, against sex trafficking at both international and national levels, were the key for this success: Coalition Against Trafficking in Women, Human Rights Watch, ECPAT International, Stop the traffik, Glogal Alliance Against Traffic in Women, etc. In Spain exist two big action platforms: Foro Social contra la Trata (brings together NGOs, public administration and experts) and RECT (Red Española contra la Trata: ACCEM, Médicos del Mundo, APRAMP, CEAR, 
Federación de Mujeres Progresistas, Women’s Link Worldwide, Mujeres en zonas de coflicto, Save the children, etc.).

This article presents relevant results of the investigation "Consumo de prostitución en España: clientes y mujeres" [Prostitution consumption in Spain: customers and women], financed by the Instituto de la Mujer del Gobierno de España [Women's Institute of the Government of Spain] during 2011-2013 ${ }^{4}$. The study will be divided into four sections: in the first one a tour is taken through the previous studies conducted on this topic, in the second, the theoretical and methodological bases that have inspired this research are exposed. The third section, epicenter of this paper, tackles the study of the customers' narrations and in the last section the achieved results and the reflections on the same are presented.

\section{Sex Customers in Scientific Literature}

The investigations that analyze, and in some cases classify, prostitution customers are relatively recent and highly descriptive, since in general they do not study in depth the reasons of the consumption of prostitution. At an international level, the pioneer author on this topic is the Swedish sociologist Sven-Axel Manson, who studied the prostitution phenomenon from the point of view of men and patronage since the decade of 1970. In 1984 Manson published Faceless sexuality. The buyer of sex, though he is best known for his work: Men's practices in prostitution: the case of Sweden published in 2001. In this book, Manson divides the customers of prostitution into four groups. The first group is composed of men that nourish the "dirty whore" fantasy. The second group is formed by those that share the idea that certain kinds of sex cannot be experienced with a nonprostitute woman. In the third group are those that, due to their fear, shyness, advanced age or physical or mental disabilities, turn to prostitution and the last group is composed mainly of young men that have a vision of sexual roles defined by images produced in today's society that are massively distributed through pornography, advertising and leisure shows (Manson, 2001, quoted in Gómez \& Pérez, 2013).

There is another significant research study conducted in France by the Mouvement du Nid (NDT) where a typology of prostitution customers is carried out. This study, headed by Claudine Legardinier and Saíd 
Bouamama, was concluded in 2006 with the book Les clients de la prostitution, l'enquête. In this book, five types of customer were identified. The first typology comprises $75 \%$ of the cases, men that justify their condition as a product derived from their own sexual, social and affective shortages. The second typology is formed by those that justify the consumption of these services by appealing to the fear, mistrust and hatred that women inspire in them. The third category includes the "commodity consumers" that invoke their condition as "buyers". The fourth category comprises those that pay in order to avoid the problems associated with every affective relation. Lastly, the fifth typology is formed by men addicted to sex (Legardinier \& Bouamama 2006, quoted in Gómez \& Pérez, 2013).

However, in most investigations the main causes that men put forward to demand this type of service are analyzed without elaborating a typology of prostitution customers. In this regard, Anne Allison, professor of cultural anthropology in the United States, analyzed prostitution consumption in Japanese clubs by Japanese businessmen in the book Nightwork: Sexuality, Pleasure, and Corporate Masculinity in a Tokyo Hostess Club. One of the conclusions of this investigation is that this consumption does not always correspond to a particular erotic interest, but to a great extent is a masculine group membership ritual and is increasingly used as organized leisure between a group of peers, as well as a patriarchal mandate, a way of demonstrating before the group of peers that they are "fully men" (Allison, 1994).

A different perspective is offered by the book Sex Markets, written by the economics professors Guista, Di Tommaso and Strom. In their research, they explore the supply and demand of prostitution and conclude that the vast majority of men use it each time they feel excited about the idea of it being illicit, about the transgression and because they think that, the woman prostitutes herself for pleasure, not for money (Guista, Di Tommaso and Strom 2008).

The sociability, the need for domination and fun are some of the reasons that are highlighted in other studies. One of the reasons sustained by the prostitution customers, sociability, is included in the research conducted in Brazil by Elisiane Pasini, where the customer is defined as a "regular" man (Pasini, 2000). The need for domination is emphasized in a paper on 
Finnish customers published by Anne-Maria Marttila, where the demand for prostitution is related to the general power structures (economic, social, cultural, local and global) and to the necessity for domination (Marttila, $2003)^{5}$. The fun feeling and the desire to try different sexual experiences is present in the book Men who buy sex. Who they buy and what they know, from the authors Melissa Farley, Julie Bindel and Jacqueline M. Golding. In this book, created from 103 interviews with prostitution customers in England, 54\% of the polled men asserted that the main motive for purchasing sex was not the absence of sexual partners but the need to receive immediate satisfaction, entertainment and pleasure as well as "variety of women" (Faley, Bindel \& Golding, 2009).

Peter Szil, a psychotherapist specialized in sexual education, associates prostitution with domination and masculine socialization in a published paper in 2004 titled Men, pornography and prostitution ${ }^{6}$. In this work, Szil asserts that: "Prostitution institutionalizes the most basic assumptions of masculine domination as social order or even as civilizing order (...) this sex grants them the right to rule their environment, the space, the time of others and, in first place, other women. This right extends as well to the body and the sexuality of women" (Szil, 2004).

In Spain, our country, the first paper that analyzes prostitution customers in Spain was written by José Luis Solana Ruiz, who published in 2002 the article "Prostitution of immigrant women in the province of Córdoba" where he distinguishes two types of Spanish customers according to their relationship with the prostitutes: the objectifiers and the personalizers (Solana, 2002).

In 2003, María José Barahona Gomáriz and Luis M. García Vicente published a book titled "An approach to the feminine prostitution customer in the Autonomous Community of Madrid" focused on prostitution customers from Madrid. From 15 interviews with Spanish customers, they extracted five reasons for paying for sexual services: affective sexual intercourses, the necessity for more frequent and varied sexual relations, the exercised power due to paying for sexual services, the desire to satisfy sexual fantasies and, lastly, the search for fun, especially as a male group experience (Barahona \& García, 2003).

Rafael López Insausti and David Baringo Ezquerra published in 2007 the article "City and heterosexual prostitution in Spain: the point of view of 
the male "customer". From 12 interviews with different typologies of consumers, the authors established six different customer categories: men that had difficulties interacting with women; men that went in groups to have fun; married men that wanted to have extramarital affairs as a minor infidelity, men that had marital problems and were searching in the payment for sexual services for certain revenge; men for whom payment for sexual services arose as an element of their work or business environment and lastly, young men that pay for sexual services because it implies less complication and effort (López \& Baringo, 2007).

In 2010, María José Barahona Gomariz published the book "Estudio sobre la información, opinión y actitud de los habitantes de Álava ante el fenómeno de la prostitución y una aproximación al perfil del cliente de prostitución femenina". The research was conducted through the completion of 452 questionnaires distributed in Álava to people over 18 years of age. $16.6 \%$ of men admitted that they had paid for sex at some point in their lives. Furthermore, 30\% of those polled did not answer this question, which leads the author to think that they have been prostitution customers but did not want to admit it (Barahona, 2010).

Also in 2010, Carmen Meneses Falcón analyzed, in the article "Factores motivacionales en una muestra de hombres españoles que pagan por servicios sexuales", the reasons that men have for paying for sex. After conducting 138 interviews, fourteen reasons for paying for sex were extracted. The three where customers agreed the most were: to be able to choose different women $(56.5 \%)$, thinking that paying for sex creates fewer problems $(46.6 \%)$ and having fast and impersonal sex $(41.3 \%)$. With the reasons offered by the customers, Meneses explains a fact analysis with the method "Extraction of principal components" and obtained six factors that could explain $80 \%$ of the variance: company, necessity, entertainment, risk, domination and speed (Meneses, 2010).

In 2012, Enrique Javier Díez Gutiérrez published "El papel de los hombres en la prostitución". In this article it is asserted that the number of men seeking for prostitutes to dominate them is increasing, more than those who search for sexual satisfaction because they have experimented a loss of power and traditional masculinity and they are not capable of creating relationships of reciprocity and respect for women (Díez, 2012). 
Gómez and Pérez published in 2009 the book Prostitución: clientes e outros homes, focused on young men and the consumption of prostitution in Galicia, Spain. In this study, 17 interviews with customers were conducted, 5 with discussion groups of masculinized collectives, 6 with female prostitutes, 2 with transsexual prostitutes, 3 with owners and managers of prostitution clubs, 1 with a worker of these clubs and 3 with social services technicians that work with female prostitutes (Gómez \& Pérez, 2009). Afterwards, this investigation was expanded to the Spanish territory during the period 2010-13, and in this article we will present the most relevant results from this research.

Is important to indicate that exists an international men movement in favour of the abolition of prostitution shaped by academicians (Luis Bonino, Peter Szil, Sergio Sinaí, Michael Kauffman, Hernando Muñoz, etc) and out-standing activists near to the feminist movements (Colectivo de Varones Antipatriarcales, Gendes, Kolectivo Poroto, National Organization of Men Against Sexism of USA, European Men Profeminist Network, Hommes contre le Patriarcat, etc). In our country this movement materializes in the "Red de hombres por la abolición de la prostitución" and it includes the men movement for equality among whom professionals stands out. Andrés Montero (psychologist), Erick Pescador (sociologist), Hilario Sáez (sociologist), and associations as AHIGE, Hombres por la Igualdad, Stop Machismo, Hombres Abolicionistas or Heterodoxia.

From the different investigations we have analyzed, prostitution service consumption by men is derived from a specific way of understanding the concept of "being a man".

\section{Masculine Discourses on Prostitution: The Customers}

In order to analyze the narrations obtained from the interviews with prostitution customers, the "frame analysis" theoretical framework was chosen (Gerhards, 1995; Goffman, 1974) with the aim of coherently structuring their narrations and classifying them in categories in order to improve use and understanding of the same. This analytic category, the "frame", stems from the "symbolic interactionism" of Goffman, currently understood as a main element for analyzing the creation of social agents' identity and its "performance". The objective is the analysis of the 
narrations' narrative structures and its coherence regarding the customers' discourses with the aim of knowing his ideological position and his interpretation of the phenomenon of prostitution. These four typologies derive from the identification of four absolute and coherent narratives that propose four forms of classification of the world regarding this phenomenon (Gerhards, 1995; Goffman, 1974). This article aims to open reflection on the causes of the purchase of sex in our country, seeking the meanings contained in this strange practice, mainly for the customers and to a lesser extent, as well for women in situation of prostitution (this topic has been researched in depth). Likewise, the impact that the relational dynamic stablish in these contexts is not trivial within the framework we are in: is an expression of the current occidental society and its affective-sexual precarisation. The hyper valuation of the total pleasure (individual) and the contrast with the leisure experiences narrated by the customers and the drama of the situation of a great number of women in prostitution, invites to ethical reflection on this social phenomenon where gender perspective cannot be avoided.

Hereafter is a description of the central framing dimensions and strategies of the ideological discourse of prostitution customers in Spain as well as their ideological manifesto, interests and ideologies from their narrations in the individual interviews and group sessions. The presented results are the outcome of research conducted during 2011-2013. It was created with the objective of understanding why men choose to pay for sex in Spanish society. To answer this question, in-depth semi-structured interviews were conducted with 29 customers, 13 female prostitutes, 3 owners of prostitution clubs or flats, 4 workers from these clubs, 23 social services technicians, academics and/or professionals of social services ${ }^{7}$. In the interviews, a thematic outline was used with the aspects to bear in mind during the conversation. The priority was to create an atmosphere of confidence and freedom to facilitate the development and transmission of the discourse. With this purpose, the aspects in mind where: motivation and causes of the consumption, frequency, type of services, valuation of the consumption and women, positive and negative experiences, meanings of prostitution.

Furthermore, 3 group interviews were conducted with groups of men from 9 autonomous communities from Spain: Andalusia, Aragón, Asturias, 
Castilla-León, Catalonia, Galicia, Madrid, the Basque Country and Valencia.

Even though the objective of this article is not to analyze the discourses of women in prostitution, we would like to highlight some aspects that the customers emphasize. The women highlight that the profile of the customers is very heterogeneous -all ages, sentimental situations, professions and education levels are represented-. Overall, they distinguish two groups of customers according to how they treat them -the "good" ones and the "bad" ones-.

I: “And, how are the men?" A: "Well, ha ha, some are brutish, but, I don't know, they... they are different, some behave well, some behave badly, you can find everything..." (Romanian, 23 years old, unemployed couple, one daughter, Club Corazón, Bierzo, 2012).

Many declare that most of the customers do not respect the initial service agreement, pretending to do some other non-agreed activities.

I: "And, how are the men?" A: "Let me see, they are undesirables, they stink... Other, well, they are nice but drunk, and sometimes they don't want to put on the glove, you have to be alert so they don't take it off, one thing, the other..." (Colombian, 37 years old, divorced, three children, León, 2011).

They also recognize that in their job they must dramatize -pretending to enjoy, worshiping the customer's ego, etc. - achieving the satisfaction of the customer.

(In order to obtain a client) A: "Hello sweetheart (with sugary voice)... what are you going to make me upstairs? This, that and that... you have to brainwash them in order to... (...)" (Colombian, 37 years old, divorced, three children, León, 2011).

From the narrations provided by the interviewed customers, we classify the prostitution customers using the "frame analysis" (Goffman, 1974). The result was the identification of four types of customers that we have denominated "misogynist customer", "consumer customer", "friend customer" and "critical customer". 
The sociological typology of the analyzed prostitution customers is wide and comprises a broad range of ages, civil status, different backgrounds and different professions (Table 1), allowing the final classification to be extrapolated to all prostitution customers.

Table 1

Typology of the 29 polled customers

\begin{tabular}{|c|c|c|c|c|}
\hline & Misogynist (6) & $\begin{array}{l}\text { Consumer } \\
\text { (10) }\end{array}$ & Friend $(8)$ & Critical (5) \\
\hline Age & $25,28,36,43,53,56$ & $\begin{array}{l}24,29,32,33 \\
34,35,37,43, \\
50,57\end{array}$ & $\begin{array}{l}21,28,32,40 \\
45,47(2), 48\end{array}$ & $\begin{array}{l}28,30,32 \\
48,50\end{array}$ \\
\hline $\begin{array}{l}\text { Civil } \\
\text { Status }\end{array}$ & $\begin{array}{l}\text { single (3) } \\
\text { married (2) } \\
\text { divorced (1) }\end{array}$ & $\begin{array}{l}\text { single (3) } \\
\text { in a } \\
\text { relationship(3) } \\
\text { married (3) }\end{array}$ & $\begin{array}{l}\text { single (2) } \\
\text { married (1) } \\
\text { divorced (3) } \\
\text { widower (1) }\end{array}$ & $\begin{array}{l}\text { single (2) } \\
\text { in a } \\
\text { relationship, } \\
\text { married (2) }\end{array}$ \\
\hline $\begin{array}{l}\text { Academic } \\
\text { background }\end{array}$ & $\begin{array}{l}\text { primary education (1) } \\
\text { secondary education } \\
\text { (2) }\end{array}$ & $\begin{array}{l}\text { secondary } \\
\text { education (3), } \\
\text { university } \\
\text { studies (4) }\end{array}$ & $\begin{array}{l}\text { primary } \\
\text { education (2), } \\
\text { secondary } \\
\text { education, } \\
\text { university } \\
\text { studies (3) }\end{array}$ & \\
\hline Profession & $\begin{array}{l}\text { salesperson, } \\
\text { administrative } \\
\text { assistant, } \\
\text { police force, } \\
\text { army officer }\end{array}$ & $\begin{array}{l}\text { salesperson, } \\
\text { shop manager, } \\
\text { martial arts } \\
\text { teacher, } \\
\text { administration, } \\
\text { secretary, } \\
\text { secondary } \\
\text { teacher (3) }\end{array}$ & $\begin{array}{l}\text { unemployed } \\
(2) \\
\text { waiter, } \\
\text { administration, } \\
\text { doctor (2) }\end{array}$ & $\begin{array}{l}\text { unemployed } \\
(2), \\
\text { salesperson } \\
(2), \\
\text { carpenter }\end{array}$ \\
\hline Ideology & $\begin{array}{l}\text { right-wing, } \\
\text { liberal, } \\
\text { independ., apolitical }\end{array}$ & $\begin{array}{l}\text { social } \\
\text { democrat (1), } \\
\text { left-wing (4) }\end{array}$ & $\begin{array}{l}\text { liberal, } \\
\text { progressive, } \\
\text { left-wing (2) }\end{array}$ & $\begin{array}{l}\text { progressive, } \\
\text { left-wing } \\
\text { (2) }\end{array}$ \\
\hline
\end{tabular}




\section{Misogynist customer}

For misogynist customers, the existence of prostitution services is something normal and necessary. They do not observe any "dark zone" in this business, adopting a critical and unreflective attitude and naturalizing the existence of prostitution because they consider it essential to mankind. From their point of view, the consumption of prostitution is logical and, according to them, general in our society:

I: "What is your opinion about prostitution?" A: "I think that it offers a necessary service for society and is in higher demand than some people would like to admit" (waiter, 21 years old, single, Ourense, 2012)

They share the perception that all women are "whores" because in their actions and in their affective-sexual relations women always have an economic and material interest. Their imagination around the "feminine world" is full of negative connotations about the woman: they consider her a perverse entity, a false and materialist human being that only acts when guided by some interest, although disguised by a passive and angelic appearance.

"A woman doesn't want sex if it's not in exchange for something... Any woman! (...). But, normally, I think that when a woman wants sex it is because she is looking for something, always marriage, or... money. Or benefits or a promotion if it's in a company or a gift..." (Military serviceman, 56 years old, divorced (marriage annulment), Zaragoza, 2011).

The image they have of prostitution is profoundly banal. They pay for prostitution services because this is the only way to have sexual intercourse with a woman. They see themselves as victims in a system where the materialistic ambitions of women force them to spend their money. However, they see it as more comfortable and less compromising than having to "flirt". They point out, ironically, that prostitution is cheaper than marriage: 
I: "So, for you, sex is almost always in exchange for money? More or less?" A:"Yes, I think so, but marriage is more expensive than that (...)" (military serviceman, 56 years old, divorced (marriage annulment), Zaragoza, 2011).

Some men have always imagined that prostitutes are free to choose them and feel real satisfaction with them. It is a sexual fantasy that they believe and maintain in order to reinforce their own hegemonic masculinity. This idea is used to eroticize the practice of prostitution:

"They enjoy it and some of them are there because they want to be... I like to go because of the "forms of seduction" that they develop, that they display... they enjoy "giving satisfaction" because to "give satisfaction is a satisfaction itself" and there is also something spiritual, transcendental in that relationship, not always, but it does happen sometimes" (secondary school teacher, 56 years old, married, Madrid, 2012)

For this type of customer women practice prostitution because they desire to, because they do a comfortable job where they have good wages with little effort:

"If she fucks it's for money, this is crystal clear, but who gets the money afterwards is another subject, isn't it? But the prostitute normally gets ninety eight per cent of the money; I am sure that if most prostitutes were offered a job washing dishes for 900 euro per month they wouldn't accept (...)" (military serviceman, 56 years old, divorced (marriage annulment), Zaragoza, 2011).

If misogynist customers understand women to be materialistic entities, they consider that men are, instead, sexual beings and genetically promiscuous. They resort to certain pseudoscientific theories to demonstrate this inevitable male tendency to sexuality:

"I very much believe in the theory of...this friend of mine... Darwin, Charles Darwin, so I think that men have some genetic predisposition to procreation, procreation, so, I'm sure that man, definitively, besides from having a feeling of satisfaction, genetically tends to have sex..." 
(Military serviceman, 56 years old, divorced (marriage annulment), Zaragoza, 2011).

Among the misogynist customers' most frequent motives to purchase sex, we should underline the search for "quality sex", a change in the routine of conjugal life and to satisfy physiological needs in order to maintain physical health and mental balance:

"Satisfaction! (Sharp) (...) lack of love... lack of sex... sometimes when I didn't have a girl, when I was younger, ha ha, I wanted to have fun and I went there... now I do it for a change... because having always the same girl... is tiresome (...)" (construction worker, primary education, 28 years old, married, Ourense, 2012).

Another reason that they use to justify their consumption is the perception that many women are not as sexually active as they are, consequently, they are forced to turn to this kind of service:

"I am incapable, but I have friends, workmates that are in here all day long and, and we say it, this is the typical Spanish macho, he has a wife, he has lovers, he picks up whores, I mean, we can't... we can't categorize... there are women that (...) are very prudish and that... they don't like sex, then... if there isn't communication in that aspect, in every aspect, but in that... sexual aspect, I think that's very important because that will end up... exploding, you will end splitting up (...) (doctor, 40 years approx., divorced, Zaragoza, 2011).

As will happen in other typologies of prostitution customers, consumption of sex within the group of colleagues or friends is the most frequent type and, in many cases, is within the "protocol" of the labor relations with customers or workmates:

I: "Is it common at work to finish the day in a club?" A:"I think so! I believe that... Seventy per cent of people! Ha! I: "Why do you think that this happens?" C:"I think that you're not at home for the whole week, don't you? And, for example, you meet with three people and one has his job, another does other work, another has another different job and ninety per cent of people say: Do you know if there's a club 


\section{MCS - Masculinities and Social Change, 4(3) 255}

around here? Yes, there is one there, let's go and have a drink..." (Farm machinery salesperson, 25 years old, single, Ponferrada, 2012).

Their uncritical and conformist attitude towards prostitution culminates in a proposal for legalization and regulation of this activity:

"If they are there, they should at least have the right to social security and that sort of thing, shouldn't they? Work is work" (construction worker, primary studies, 28 years old, married, Ourense, 2012).

The customers belonging to this typology adopt an opinion that is sexist and contrary to gender equality policies, even expressing an incredulous attitude towards male violence against women:

(Regarding gender equality) "I think that this is a movie that left winged governments invented to generate work...positions, to generate positions because, honestly, we'll never be equals because you can't distinguish between two things that are equal, but you can distinguish a man from a woman perfectly" (Worker from the hotel and restaurant industry, secondary studies, 53 years old, single, Ourense, 2012).

Misogynist customers see in prostitution an environment where they can maintain their position of masculine power that, according to them, has been eroded by gender equality policies:

(On prostitution) "Something they sell and we buy (...) but is like a power relation; what I mean is that I pay so you do as I want, right? (...) Power through money (...) by having this feeling of power, maybe is used to take out a lot of frustration..." (Martial arts teacher, 50 years old, divorced and in a relationship, A Coruña, 2011).

\section{Consumer Customer}

From our research, we have obtained a hegemonic discourse of common places from young people, an explicitly non-sexist discourse that is critical with the chauvinist male inheritance from the past. They are young men, generally sufficiently educated and well informed, that share hedonistic consumption ethics and have a weak and dependent economic base, since 
most of them still live with their families. They consider that nowadays people have more freedom in all sorts of relationships, including sexual intercourse. They think that the stereotype of women that only seek love and men that only seek sex is merging. For them, both genders look for the same:

"There's always this prejudice: that men only go for that, I mean, sex; and that women seek the affective part, but I think that is only a prejudice, the truth be told" (GD2, students, economics, Cordoba, 2011).

They think of women as equals. In their opinion, both genders are active in all fields (social, labor and sexual), although they recognize that women are still suffering from some discrimination and inequality:

"The truth is that I think that things are way better than some years ago, although we can find some differences, especially in the employment sphere. In the remaining areas, sexuality or society, I think that there are few differences between men and women" (administration worker, vocational training, 29 years old, unmarried and in a relationship, Ourense, 2012).

Nevertheless, they do recognize that sexual freedom is still more severely punished for women than for men, something that they consider unfair:

"Yes, that is still present: if a man picks up many girls he is a champion, yet a woman that has sex with several guys is a whore. I don't know how long this will last, but it is indeed unfair; but it's something rooted in society and it's very difficult to eliminate it" (GD2, economics students, Cordoba, 2011).

The consumer customer senses the existence of women that are sexually exploited against their will, which is a situation that they resolve from a consumerist perspective, "buying what is being sold", as a consumer of clothes manufactured by labor and child exploitation: 
"Most of them (women in prostitution) are exploited, I think... women, look, they are in a situation that I don't think they would be if they could choose (...) but no, I don't think it's wrong" (civil servant, teacher, 35 years old, single, Ourense, 2012).

Some customers within this typology appear to defend gender equality, which leads them to criticize chauvinist male attitudes. However, this defense is more theory than practice because their freedom and rights as consumers are above other kinds of considerations of an ethical or ideological nature:

"I think that there should be gender equality, but I don't think it is something that can be easily appreciated in today's society (...). A case in point, at home my wife is still the one that has the burden of the household, I'm embarrassed about that and I try to gain ground but she is way more organized than I am and I wish I was like her" (secondary education teacher, 43 years old, married, Ourense, 2012).

Among these young men, a non-sexist, less chauvinistic vision is shared in comparison to previous generations but, paradoxically, this perspective on gender equality is not applied in the prostitution field. A contradictory stance is observed: they search for equal women to be their partners...

"Look, in my case, the ideal woman, the physical appearance... Of course I have to like her but she should share my ideas and my way of being, because she can be a beauty but if nobody can stand her... this is essential (...) you should be able to speak to her about any matter" (civil servant, teacher, 35 years old, Ourense, 2012)

And, at the same time, they search for prostitutes and treat them as commodities, just as another consumption product, a McSex consumption, quick, frugal, with scarce quality and without commitment. This way they can conciliate non-sexist opinions with the purchase of sex: the field of prostitution is another consumption market for them.

This mercantilist point of view complements itself with a value system where individualist hedonism and the search for satisfaction are driving their lives: 
(Sexual intercourse) "It was usually the same, they were already doing their job, they are professionals, they are like (...) because they work for you to feel horny" (teacher, 35 years old, single, Ourense, 2012).

It is frequent for sex consumption to be done due to social matters, trying to emulate a group of friends. This last reason is related to a type of masculine guild subculture that reinforces the union of the group through common complicity, transgression and fun between friends because, in the end, it is the group that confers your masculine identity (Connell, 1996) ${ }^{9}$ :

"Once I knew that at a stag party there were things related to prostitution but I didn't intervene regarding touching the woman or regarding the things that could have happened during that night (...) (Secondary school teacher, 43 years old, married, Ourense, 2012).

In many cases, these group practices occur the first time as an initiation to "become a man":

"It was in group celebrations (...) I suppose we were going for fun (...) but of course I wasn't there for sexual reasons, some friends of mine were, I suppose, but not me, and not for fantasy either (...) it was for fun (...) it was like giving the "macho" a girl when he has to become a man (...) I do remember it now as an initiation ritual" (secondary school teacher, 43 years old, married, Ourense, 2012).

In some of their narrations there is certain self-criticism with their past as customers: they participated because of "young foolishness":

"We were going around once or twice per year (...) that was for some years, I don't know, four or five... pre-adult gibberish, ha ha ha (secondary education teacher, married, Ourense, 2012).

The union of this non-sexist partial point of view which at the same time is mercantilist and consumerist ends in a position favoring the legalization and regulation of prostitution, granting, above all, "quality", because hygienic and sanitary controls of the sold "product" will be performed. 


\section{MCS - Masculinities and Social Change, 4(3) 259}

In a free market society, this activity should be regulated in order to guarantee the right conditions to develop the activity as well as guaranteeing minimal security conditions regarding hygiene and material safety for customers and for the prostitutes" (manager of a computer shop, 34 years old, single, Ourense, 2012).

\section{Friend Customer}

In this typology are those men that adopt a "kind" attitude when purchasing sex. These customers are able to humanize prostitutes and "empathize" with them. For them, women that practice prostitution do so mainly because they have no other option:

"It's sad that there are women that have to do this, but, in general, if they do it, it is their last resort and this is absolutely better than stealing (...)" (RENFE employee (state-owned company that operates Spanish freight and passenger trains)primary education, 45 years old, widowed, Ourense, 2011).

They think that their good practices as lovers make a difference between them and other customers, because they know how to give satisfaction to prostitutes. This is why they have an image of themselves as luxury customers, because they achieve that the prostitutes forget about their economic benefits for the sake of enjoying their time with them, because they treat them well and give them satisfaction. This attitude drives them, in some cases, to establish emotional bonds that recreate the ties arising from a situation of "casual flirting" or the beginning of a love relationship.

"Some loved it, even, well, you know? They give you their telephone number and say "call me so we can go out together" and I don't know, this happened to me several times and one even fell a little in love with me (...)" (martial arts teacher, 50 years old, divorced and in a relationship, A Coruña, 2011).

In the "prostitution" context there is a certain "dramatization" by women flirting and, during the sexual intercourse, making the customer believe that he possesses wonderful qualities that give them satisfaction and orgasms, 
but everything is pretend and dramatized in order to make the customer to feel good, as an "excellent lover".

"Even though the customer believes it and I can vouch for it by what I have listened to, the woman is getting laid for money, not for affection, nor for love, nor even for the sex and maybe it's disgusting for her (interview with a social technician, Proyecto Érguete Muller, Ourense, 2011).

Even though sexual necessities appear among the motivations declared for purchasing sex, other motivations are abundant as well, for example, covering affective aspects, the search for certain human warmth, company or friendship:

"After being married for more than 20 years and without any children, on one side I need to feel affection, I do have some affective necessities and I can cover them, at least temporarily, this way" (RENFE employee, primary studies, 45 years old, widowed, Ourense, 2011).

Sometimes they even recognize that consuming prostitution is not a decision that makes them proud. The friend customer often argues that the consumption is produced in situations of meetings, parties with friends or colleagues:

"I have gone to have a drink but I didn't consumed, but (takes breath) but this happens when we dine out, you go to have dinner with some friends "let's go there, let's go there!" and I don't like it, I don't like to go upstairs, I don't like it but I do go and I have fun, I have some drinks, I pay some drinks for the girls... but I don't like to go upstairs" (unemployed, secondary education, 47 years old, divorced, Barbadás, 2012).

This type of customer usually supports regulatory positions regarding prostitution, but consider that its regulation is complex::

"The regularization of this activity, including medical inspections, would reduce the frequency of these effects, that may reach the family 
of the men that use these services, having, as consequences, the infection of sexually transmitted diseases" (doctor, divorced, Ourense, 2011)

\section{Critical Customer}

The narrative typology of the critical or repentant customer is less abundant among the interviewed customers up to now. They hold a critical point of view, where the existence of gender inequality and injustices suffered by women in a patriarchal and capitalist environment are recognized. For them, this inequality aggravates in as much as we descend the socioeconomical scale, the origin and legal status of women inside prostitution. This is the reason why the critical customer considers that women in prostitution are one of the most vulnerable social groups. According to them, women practice prostitution because of necessity, being, sometimes, victims of mafias that exist in the prostitution field:

I: "What is your opinion about prostitution?" A: "It's a very complicated job, there is no legislation, it moves a lot of money, there are mafias involved and some of these women are enslaved and suffering from aggressions, extortions, blackmail..." (Insurance intermediary, 48 years old, married, Ourense, 2011).

The critical customer considers that there are a larger number of privileges intended for men and, besides, that there is greater control over the emotional and sexual life of women:

I: What was the feeling you had from the women in there, engaged in prostitution? A:"Puffff!! At that moment I didn't think about it but I did after... What a shitty life!!! Basically they are enslaved there, I was impressed by some of them with marks on their faces, some scars and I did link it, for sure it was some trafficking, they must be treated worse than if they were dogs because some of them had scars" (carpenter, 28 years old, in a relationship, A Pobra do Caramiñal, 2011).

They assert that the reasons for the consumption of sex are not the ones that men usually talk about, but rather other reasons related to the power situation that they have in the prostitution context are hidden because in this 
context they can relieve their daily frustrations through the humiliation and abuse of these women.

"If you feel inferior, there you have an opportunity to feel superior and to do what you really want (...) We went upstairs, some guys and some girls and I didn't like it because I felt a role of superiority, that you want to be more, right? Abuse in itself, some superiority..." (Carpenter, 28 years old, in a relationship, A Pobra do Caramiñal, 2011).

The customers belonging to this typology develop a discourse where another motivation for men that purchase sex remarked: the increase of the commercialization of human relationships, which provokes the search for sex and affection in separate ways.

"I imagine that this is something beyond pure and simple sex and that there would be people only interested in getting laid, but I do consider that another story is (...) looking for someone to do a blow-job for 15 euro, stop, finished... then people look for that, those five or ten minutes and the guy got relief" (salesman, 50 years old, married, Santiago de Compostela, 2012).

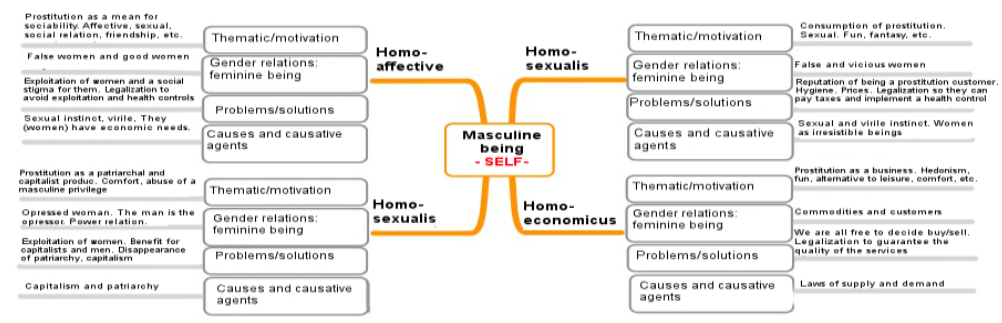

Figure 1. Diagram with the four typologies of prostitution customers 


\section{Final Reflections}

In contemporary western societies, mass consumption of prostitution services by male population is one of the most significant indicators of a way of understanding, living and feeling sexuality, is a glimpse of the regulatory standard of affections and sexuality of our historic time.

Contrary to expectations, prostitution has acquired an unsuspected and unpredictable relevance in the context of sexual liberation that seemed to indicate a gradual disappearance. Prostitution has expanded and diversified, turning into an activity legitimized by the post-capitalist system itself, in a context of exploitation that is ever more standardized. From a tour around all existing scientific literature and around the empirical research, this article on prostitution in Spain has focused on the study of the prostitution customer, trying to understand why men, the main consumers of prostitution in Spain, pay for sex.

All specific discourses, through the different customer typologies, have answered these; why, how, when, how much, with whom, etc. is the purchase of sex produced with the aim of clarifying the reasons and causes of the high consumption of this service in Spain. In general, the four typologies share a culture prostitution and porn -erotic, besides use prostitution as an "initiation rite" towards the reaffirmation of a masculinity characterized by its narcissism and accumulative sexuality. Taking into account the results of other researches as well as the analysis of the discourses of interviewed customers, the existence of a masculine subculture in a porn-capitalist context can be deduced. This subculture fixes the most traditional patriarchal values and has as identity base male chauvinism and the exercise of a type of masculinity where frequent encounters with women through the "use of phallus" is decisive to self recognition and to show of in front of the group of peers (Gómez \& Pérez, 2013).

The typologies obtained in this research have a high degree of coincidence with other similar studies done in this field. . In fact, we can find in all the typologies two groups of customers. The first group is composed of those men that seek in prostitution the satisfaction of needs outside the sex sphere, as domination, experiment risks or company, identifying in some of them the customers' subgroup "misogynist" and 
"friend" (Legardinier \& Bouamama, 2006 quoted in Gómez \& Pérez, 2013). The second group of customers is formed by those men that demand sex as a category of leisure, as a leisure activity. Emerges as well in some the subgroup of young men, who use the consumerist logic in their discursive narrations (Gómez \& Pérez, 2013). In the rest of researches is not carried out a typology of customers but some of these motivations emerge in the discourses of prostitution customers: to satisfy a need of domination (Marttila, 2003; Díez, 2012), socialize through prostitution (Allison, 1994; Pasini, 2000; López \& Baringo, 2007) or increase the frequency and/or the variety of sexual encounters (Farley, Bindel \& Golding, 2009).

Nevertheless, in our research we have gone further, conducting a characterization of customers in each typology. In the misogynist customer typology there is a prevalence of men with a lower education level that identify themselves with right-winged politics. At the other end, among men with the critical customer typology, are those who have a higher educational background and define themselves left wing oriented ${ }^{10}$.

The analyzed individuals displayed their particular "emic" perspective about the reasons, causes and opinions related to prostitution consumption but it is from their "etic" perspective where the total dimension can be interpreted. Through the "frame analysis" theoretical perspective used, and from sociological meanings, an understanding of this social reality has been reached.

In the end, this scientific research identifies a set of extra-sexual causes related to payment for sex: the search for dominance, entertainment, affection, sociability, desire for consumption of new "commodities", etc. (Legardinier \& Bouamama, 2006; Szil, 2004; Barahona, 2010; Barahona et al., 2003; López \& Baringo, 2007; Meneses, 2010). In no case have we found discourses from lovers of pleasure for pleasure as a magnificent and transcendent act. The causes and motivations are different and from our point of view, are related to the building of a dominant and patriarchal masculinity that is still hegemonic in our society. As far as we are concerned, the purchase of sex (justified by the affirmation of the search for quality sex, fun and hedonistic pleasure, etc.) answers to a patriarchal mandate and to a strategy, not necessarily conscious, or to reinforcement of a masculinity created by an identity devoted to exhibition in front of a 
group of peers, the "use of the phallus" and frequent sexual practices with women.

In our work hypothesis, it is considered that the purchase of prostitution services is directly related to contemporary masculinities, built in relation to compulsive sexual practices and the need to have male witnesses in order to reinforce their masculinity in public. The dominant masculine identity is focused on a narcissistic "phallocentrism" that shifts the traditional role (father, protector and supplier) and is built in relation to "other" men. This type of masculinity is sheltered, reproduced and legitimated in spaces of prostitution. The elements where this dimension is fostered are collective consumption, the pact of silence shared by the customers and groups of friends (what happens inside the club should not transcend) and the presence/use of the phallus. These elements create an impeccable code shared by the virilized subjects, the "prostitution subculture" that can be considered as another exponent of human rights violations and gender violence.

The pernicious and adverse effects of the excess commercialization and objectification of human beings would be rejected in other identity models where other ways of masculinity are reinforced. These models are based on integral personal development, just as much as on the physical, mental and social activity of men, fostering a pleasant and healthy sexual life, developed within the framework of respectful, equal, fair and caring social relationships among men and between men and women.

This paper tries to open reflection on the reasons of massive consumption of prostitution as indicator of a sexual hegemonic culture with enormous lacks in affective and educational matters and the contrast that exists between the banal and insensitive attitude that the customers adopt opposite to the dramatic quality of the situation of women in prostitution. Prostitution turns out to be a re-foundation ritual of patriarchy though the choice of a propitiatory victim: the woman.

From our point of view, in a world where globalization is constantly increasing, it is necessary to reflect on human sexuality. There are other forms of interpreting affection, gender and sexuality in order to be able to develop an alternative "epistemology" that will help to build a fairer and more equitable world. 


\section{Rosa Verdugo - The Problem of Prostitution in Spain}

\section{Notes}

${ }^{1}$ Assuming the current cultural meanings of prostitution in our society, we should consider the "customer" as the main actor that executes the main and primary responsibility for the existence and permanence of the phenomenon and, as a result, the necessity of designating him as "prostitutor" (prostitution agent). However, in this text we will use the "market" meaning of "customer", as it is the standard.

${ }^{2}$ This data places the sex industry as the third most profitable industry in the world, after arms trafficking and drugs trafficking.

${ }^{3}$ From October 2014, the INE, Instituto Nacional de Estadística [Spanish Statistical Office], will include the impact of this industry in the informal economy in Spain. There is certain uncertainty as to how the impact of prostitution and drugs will be calculated on the economy, because there are no official data.

${ }^{5}$ Garafalo also carried out research on prostitution customers in Europe, where he asserted that the relations established between customers and prostitutes are based on power, gender, class and race (unpublished investigation quoted in Gimeno, 2012).

6 This paper is available at szil.info/es/system/files/document/101-hombres-pornografiaprostitucion.pdf

${ }^{7}$ Within the NGO, we have identified a triangle structure that differentiates three discursive typologies. The first one is consisted of abolitionists, those that consider that prostitution is another expression of gender violence. The second one consists of the technicians, women that carry out welfare actions with women on prostitution; they do not comment or possess a meta-narrative in order to understand and interpret the phenomenon of prostitution; they are aware of the existence of networks that exploit women but do not develop a positioning regarding this matter. The third one consists of the pro-legalization group, that consider prostitution as a job, as decent as any other job; their discourse is placed in the fight against the stigmatization and margination of women in prostitution and their customers, against sex trafficking, exploitation and abuse within the rights framework of every worker.

${ }^{8}$ Between brackets is the number of individuals.

${ }^{9}$ Raewyn Connell defines masculinity as a position in gender relations; and as a practice through which men and women occupy that gender position. In order to describe the process of building this masculinity, Connell focused his analysis on the relationships among men, more than man-woman relationships.

${ }^{10}$ As this is a structural sample and not proportional we can not affirm, in a restricted sense, that exists a formative profile in each of the customers' typologies. In fact, within the category of "friend customer" we have found men belonging to every formative level. 


\section{References}

Allison, A. (1994). Nightwork: sexuality, pleasure and corporate masculinity in a Tokyo Hosstes Club. Chicago: University of Chicago Press.

Barahona Gomariz, M.J. (2010). Estudio sobre la información, opinión y actitud de los habitantes de Álava ante el fenómeno de la prostitución y una aproximación al perfil del cliente de prostitución femenina. Vitoria: Asociación Gizarterako.

Barahona Gomariz, M.J. and García Vicente, L.M. (2003). Una aproximación al perfil del cliente de prostitución femenina en la Comunidad de Madrid. Madrid: Publicaciones de la Dirección General de la Mujer.

Bourdieu, P. (2000). La Dominación Masculina. Barcelona: Anagrama. Butler, J. (2001). La cuestión de la transformación social. In: E. BeckGernsheim, J. Butler and L. Puigvert, Mujeres y transformaciones sociales (pp.29-30). Barcelona: El Roure.

Chodorow, N.J. (1989). Feminism and Psychoanalytic Theory. Cambridge: Polity Press and New Haven: Yale University Press.

Connell, R. (1996). Masculinities. United Kingdom: Politiy Press.

Connell, R. (2003). Masculinidades. Programa Universitario de Estudios de Género. México: Universidad Nacional Autónoma de México.

Díez Gutiérrez, E.J. (2012). El papel de los hombres en la prostitución, Nuestra bandera: revista de debate político, 232, 39-54.

Farley, M. et al. (2009). Men who by sex. London: Eaves.

Gamson, W. (1990). The strategy of social protest. California: Wadsworth Publ.

Gerhards, J. (1995). Framingdimensions and framing strategies: contrasting ideal-and real-typeframes. London: Social Science Information.

Gilligan, C. (1982). In a different voice. Harvard: University Press.

Gimeno, B. (2012). La prostitución. Barcelona: Bellaterra.

Gilmore, D.D. (1990). Manhood in the Making: Cultural Concepts of Masculinity. New Haven: Yale University Press.

Giusta, M.D. et al. (2008). Sex Markets. A Denied Industry. London and New York: Routledge. 
Goffman, E. (1974). Frame analysis. Cambrigde: Harvard University Press. Goldberg, S. (1973). The Inevitability of Patriarchy. New York: Willian Monrow and Company.

Gómez, A., and Pérez, S. (2009). Prostitución: clientes e outros homes. Vigo: Edicións Xerais.

Gómez, A.and Pérez, S. (2013). Informe técnico. Consumo de prostitución en España: clientes y mujeres. Madrid: Instituto de la Mujer (inédito).

Guillette, D. and Moore, R. (1993). La nueva masculinidad rey, guerrero, mago y amante. Madrid: Paidos Iberica.

Ibarra, P. and Tejerina, B. (comp.) (1998). Los movimientos sociales.

Madrid: Trotta.

Irigaray, L. (1998). Ser Dos. Buenos Aires: Editorial Paidós.

López Insausti, R., and Baringo Ezquerra, D. (2007). Ciudad y prostitución heterosexual en España: el punto de vista del 'cliente' masculino, Documentación Social, 144, 59-74.

McAdams, D. et al. (comp.) (1999). Movimientos sociales: Perspectiva comparada. Madrid: Itsmo.

Marttila, A.M. (2003). Consuming sex: finish male clients and Russian and Baltic prostitution. 5th European Feminist Research Conference. University of Lund, Sweden.

Meneses Falcón, C. (2010). Factores motivacionales en una muestra de hombres españoles que pagan por servicios sexuales, Revista de la Asociación Española de Neuropsiquiatría, 30(107): 393-407.

Ortner, S. (1979). ¿Es la mujer al hombre lo que la naturaleza a la cultura? In H.L. Moore (Ed.) Antropología y feminismo (pp.109-131).

Madrid: Anagrama.

Otegui, R. (1999). La construcción social de las masculinidades, Política y Sociedad, 32, 151-160.

Parsons, T. (1999). El sistema social. Madrid: Alianza Editorial.

Pasini, E. (2000). Límites simbólicos corporais na prostituçao feminina, Cadernos Pagu, 14, 181-200.

Preciado Ruiz, B. (2002). Manifiesto Contra-Sexual. Madrid: Opera Prima. Snow, D. et al. (1993). Framing proceses and identity construction in collective action. Paper presented at the Annual Meetings of the Midwest Sociological Society, Chicago, USA. 
Solana Ruiz, J.L. (2002). Prostitución de mujeres inmigrantes en la provincia de Córdoba. In F.J. García Castaño et al. (coord.), $L a$ inmigración en España: contextos y alternativas (pp.37-57). Granada: Universidad de Granada.

Szil, P. (2004). Los hombres, la pornografía y la prostitución. Retrieved from http://szil.info/es/system/files/document/101-hombrespornografia-prostitucion.pdf

Tarrow, S. (1997). El poder en movimiento. Los movimientos sociales, la acción colectiva y la política. Madrid: Alianza Universidad.

\begin{abstract}
Águeda Gómez is Senior Lecturer in the Department of Politic Science; Management, Philosophy and Moral Philosophy at the Universidad de Vigo, Spain.
\end{abstract}

Contact Address: Direct correspondence to Águeda Gómez, Facultad de Ciencias de la Educación (Ourense, España) - Universidad de Vigo - R/ Doctor Temes, s/n, 32004 Ourense, email: agueda@uvigo.es

Silvia Pérez is Sociologist.

Contact Address: Direct correspondence to Silvia Pérez, C/ Freixo, ${ }^{\circ}$ 19, portal 3, $4^{\circ} \mathrm{E}, 36940$ Cangas (Pontevedra), Spain, email: silviapf@uvigo.es

Rosa Verdugo is Senior Lecturer in the Department of Applied Economics at the Universidad Santiago de Compostela, Spain.

Contact Address: Direct correspondence to Rosa Verdugo, Facultade de Económicas e Empresariais - Avda. do Burgo das Nacións, s/n. Campus Norte 15782 Santiago de Compostela, email: rosa.verdugo@usc.es 